\title{
Selenium prevents lithium accumulation and does not disturb basic microelement homeostasis in liver and kidney of rats exposed to lithium
}

\author{
Małgorzata Kiełczykowska, ${ }^{1, A, D, F}{ }^{\oplus}$, Małgorzata Polz-Dacewicz ${ }^{2, E}{ }^{\oplus}$, Ewelina Kopciał ${ }^{3, B-C \oplus}$, \\ Olga Mitrus ${ }^{1, B-C \oplus}$, Jacek Kurzepa ${ }^{1, D-E \oplus}$, Zbigniew Marzec ${ }^{3, D \oplus}$, Irena Musik ${ }^{1, C-E \oplus}$ \\ ${ }^{1}$ Chair and Department of Medical Chemistry, Medical University, Lublin, Poland \\ ${ }^{2}$ Department of Virology, Medical University, Lublin, Poland \\ ${ }^{3}$ Chair and Department of Bromatology, Medical University, Lublin, Poland \\ A - Research concept and design, B - Collection and/or assembly of data, C - Data analysis and interpretation, \\ $D$ - Writing the article, E - Critical revision of the article, F - Final approval of article
}

\begin{abstract}
Kiełczykowska M, Polz-Dacewicz M, Kopciał E, Mitrus O, Kurzepa J, Marzec Z, Musik I. Selenium prevents lithium accumulation and does not disturb basic microelement homeostasis in liver and kidney of rats exposed to lithium. Ann Agric Environ Med. 2020; 27(1): 129-133. doi: $10.26444 /$ aaem/105926
\end{abstract}

\begin{abstract}
I Abstract
Introduction. Lithium has been used in medicine for almost seventy years. Besides beneficial effects, its therapy may cause serious side-effects, with kidney and liver being the organs most vulnerable to its harmful influence. Therefore, research on protective agents against lithium toxicity has been continuing for some time.

Objective. The aim of the present study is to evaluate the influence of additional selenium supplementation on lithium content, as well as homeostasis of the essential microelements iron, zinc, copper and manganese in kidney and liver of rats undergoing lithium exposure.

Materials and method. The study was performed on 4 groups of male Wistar rats ( 6 animals each) treated with: control - saline; Li-group - $\mathrm{Li}_{2} \mathrm{CO}_{3}$ at a dose of $2.7 \mathrm{mg} \mathrm{Li} / \mathrm{kg}$ b.w.; $\mathrm{Se}$-group - $\mathrm{Na}_{2} \mathrm{SeO}_{3}$ at a dose of $0.5 \mathrm{mg} \mathrm{Se} / \mathrm{kg}$ b.w.; Li+Se-group both $\mathrm{Li}_{2} \mathrm{CO}_{3}$ and $\mathrm{Na}_{2} \mathrm{SeO}_{3}$ at doses of $2.7 \mathrm{mg} \mathrm{Li} / \mathrm{kg} \mathrm{b.w.} \mathrm{and} \mathrm{of} 0.5 \mathrm{mg} \mathrm{Se} / \mathrm{kg}$ b.w., respectively, in the form of water solutions by stomach tube, once a day for 3 weeks. The content of the studied elements in the organ samples was determined using flame atomic absorption spectroscopy (FAAS).

Results. Lithium administered alone caused a significant increase in its content in liver and kidney. Additional supplementation with selenium reversed these effects, and did not markedly affect other studied microelements compared to control.

Conclusions. The obtained results suggest that selenium could be regarded as an adjuvant into lithium therapy. However, considering the limitations of the present study (the short duration, using only one dose and form of selenium) the continuation of the research seems to be necessary to clarify the influence of selenium supplementation on basic microelements and lithium accumulation in organs during lithium exposure.
\end{abstract}

I Key words

lithium, selenium, iron, zinc, copper, manganese, male rats, liver, kidney

\section{INTRODUCTION}

Lithium, proposed as an essential trace element, has been used in the therapy of psychiatric disorders for almost 70 years $[1,2]$. Furthermore, recently, a resurgence of concern in its application, prompted by its effectiveness and anti-suicide action, has been reported [3]. Lithium therapy has also been revealed to be safe even in adolescents and children [4]. Moreover, the possibility of its use in other pathological states has been reported, e.g. as an adjuvant in the cure of leukaemia or thyroid disorders $[5,6]$. However, despite beneficial action, the therapy may carry side-effects, affecting both life conditions and compliance of patients in a considerable way. Lithium's side-effects include hypercalcaemia, gastrointestinal, dermatological, cardiovascular, renal, as well as thyroid and parathyroid disorders $[2,7,8,9,10$,

Address for correspondence: Małgorzata Kiełczykowska, Chair and Department of Medical Chemistry, Medical University of Lublin, Lublin, Poland

E-mail: malgorzata.kielczykowska@umlub.pl

Received: 22.01.2019; accepted: 25.03.2019; first published: 12.04.2019
$11,12]$. Research has revealed its harmful influence on the functions of key organs, including liver and kidney $[2,10$, $13,14]$ with the latter being particularly vulnerable $[3,15,16]$. An additional problem results from the fact that both the serum therapeutic lithium concentration and the dose required for its maintenance decrease with the age of the patients [11]. Additionally, animal research revealed lithium's accumulation in organs resulting from oral exposure [14]. The enhanced using of lithium in industry and subsequent contamination of the environment may also contribute to its accumulation in living organisms as it has been reported to be considerably bioavailable from water [17]. For these reasons, research on protective agents has been carried out with rather encouraging outcomes $[2,10,13,18]$.

Selenium is ranked among the microelements which, although they occur in very small amounts, exert a large effect on the functions of living organisms. As a constituent of the enzymes glutathione peroxidase, thioredoxin reductase, and iodothyronine deiodinase, selenium takes part in antioxidant defence and affects thyroid functions [19]. A low selenium 
level in organisms has been found to be connected with the incidence of numerous disorders [20, 21, 22]. Animal research has also revealed disturbances in the selenium level in kidney occurring in diabetes [23]. Furthermore, animal model research revealed antidepressant-like properties of selenium compounds, while human studies showed some relationships between low environmental selenium level and incidence of depression, as well as the protective effect of selenium supplementation against depression [19]. Additionally, selenium has already been revealed to show protective action against harmful factors causing injury to organs, including kidney [24].

\section{OBJECTIVE}

The current study was performed with the aim of evaluating the influence of lithium, selenium and co-treatment with these 2 elements on the homeostasis of the chosen microelements (iron, copper, zinc and manganese) in the liver and kidney of rats. Apart from contributing to knowledge of lithium and selenium relationships with the essential microelements, an attempt was made to estimate whether selenium supplementation could play a protective role in lithium-treated subjects. The bioelements were chosen taking into account their importance for the proper functions of the organism, as well as involvement in psychiatric disturbances $[1,19]$. Liver and kidney were chosen, taking into account their detoxifying functions, as well as susceptibility to the influence of lithium. Animal studies seem to be most valuable, as in the case of humans, blood is the only available material and it is impossible to evaluate changes occurring in the organs.

\section{MATERIALS AND METHOD}

The study was performed on adolescent male Wistar rats (130 - $160 \mathrm{~g}$ body weight). After a 3-day acclimatization period, the animals were randomly divided into 4 groups ( 6 animals each) and subjected to the experimental treatment for 3 weeks. During all treatments, the rats had free access to drinking water and standard feed LSM (AGROPOL S.J., Motycz, Poland) with no lithium and selenium supplementation. Details of the study design are presented in Figure 1.

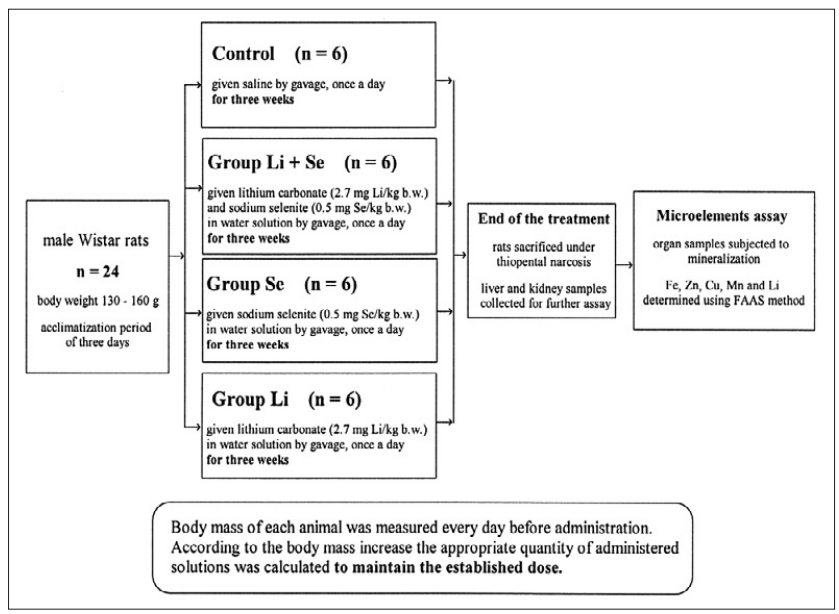

Figure 1. Experimental design
The used doses of selenium ( $0.5 \mathrm{mg} \mathrm{Se} / \mathrm{kg}$ b.w.) and lithium (2.7 mg Li/kg b.w.) were based on previous studies performed in our Department concerning the effect of selenium supplementation and lithium exposure on animal organisms $[25,26]$, as well as on available literature data $[27,28]$. The dose of lithium was comparable with that used in the therapy of bipolar disorders.

After the end of the administration period the rats were sacrificed and samples of liver and kidney were collected. The contents of iron, zinc, copper, manganese and lithium were determined using flame atomic absorption spectroscopy (FAAS), as described previously [29].

The experiment was performed according to statutory bioethical standards and approved by the I Local Ethical Commission of the Medical University in Lublin, Poland (Acceptance No. 1/2013).

STATISTICA programme (version 10.0) was used for statistical analysis. The normality of data distribution was verified by Shapiro-Wilk test. Analysis of the differences among the studied groups was performed with the application of a one-way analysis of variance (ANOVA), followed by Tukey test (normally distributed variables) or Kruskal-Wallis one way analysis of variance (non-normally distributed ones). Values were considered significant with $\mathrm{p}<0.05$.

\section{RESULTS}

No statistically significant differences were observed among the studied groups in the case of iron content in liver. The value obtained in rats given lithium, selenium or both elements, showed no difference compared to control, with the least difference being observed in the case of the $\mathrm{Li}+\mathrm{Se}$ group ( $\mathrm{p}=0.16968, \mathrm{p}=0.57364, \mathrm{p}=0.97998$, respectively) (Tab. 1). Similar results were obtained for kidney, with the value for the $\mathrm{Li}+\mathrm{Se}$-treated group differing the least compared to control ( $\mathrm{p}=0.87546$ for Li-group, $\mathrm{p}=0.24334$ for Se-group, $\mathrm{p}=0.90493$ for $\mathrm{Li}+\mathrm{Se}$ one) (Tab. 2). The same lack of statistically significant differences was observed in the case of zinc in both organs (Tab. 1, Tab. 2). The p values for $\mathrm{Li}$, Se and $\mathrm{Li}+\mathrm{Se}$ groups vs. control were as follows: 0.93161, $0.77571,0.98384$ in the case of liver and 0.99511, 0.93161, 0.99138 for kidney. Copper content in liver did not show any significant differences among the studied groups with the $\mathrm{p}$ values compared to control being 0.99788, 0.52685, 0.99984 for $\mathrm{Li}, \mathrm{Se}$ and $\mathrm{Li}+\mathrm{Se}$ groups, respectively (Tab. 1). Similarly, the differences in copper content in kidney were found to be statistically insignificant with $\mathrm{p}=1.00000$ in all cases (Tab. 2). Manganese content in both liver and kidney showed no significant differences among the studied groups with $\mathrm{p}=1.00000$ for $\mathrm{Li}$, Se and $\mathrm{Li}+\mathrm{Se}$ groups compared to control (Tab. 1, Tab. 2). Distinct from the other studied elements, statistical analysis showed significant differences in lithium content in liver. In animals receiving lithium, the tissue content of this element was significantly increased compared to all other groups ( $p=0.00018$ vs. control; $p=0.00018$ vs. Se administered group; $\mathrm{p}=0.00018$ vs. $\mathrm{Li}+\mathrm{Se}$ treated group). The values obtained in the $\mathrm{Se}$ and $\mathrm{Li}+\mathrm{Se}$ groups did not differ markedly compared to control $(\mathrm{p}=0.98468, \mathrm{p}=0.81288$, respectively) (Tab. 1).

The same findings were obtained for kidney. A significant enhancement of lithium content in the Li-treated group compared to control $(\mathrm{p}=0.00026)$ was accompanied with 
Table 1. Content of the studied elements in liver of rats receiving lithium and/or selenium in $\mu \mathrm{g} / \mathrm{g}$ of wet tissue

\begin{tabular}{|c|c|c|c|c|c|}
\hline Group & $\mathrm{Fe}$ & $\mathrm{Zn}$ & $\mathrm{Cu}$ & $\mathrm{Mn}$ & $\mathrm{Li}$ \\
\hline C & $\begin{array}{c}97.58 \pm \\
10.23 \\
\text { a }\end{array}$ & $\begin{array}{c}34.87 \pm 2.79 \\
\mathrm{a}\end{array}$ & $\begin{array}{c}4.69 \pm 0.41 \\
a\end{array}$ & $\begin{array}{c}1.288 \pm \\
0.059 \\
a\end{array}$ & $\begin{array}{c}0.0295 \pm \\
0.0079 \\
a\end{array}$ \\
\hline $\mathrm{Li}$ & $\begin{array}{c}119.49 \pm \\
16.31 \\
\text { a }\end{array}$ & $\begin{array}{c}33.56 \pm 2.41 \\
a\end{array}$ & $\begin{array}{c}4.64 \pm 0.42 \\
a\end{array}$ & $\begin{array}{c}1.213 \pm \\
0.180 \\
\text { a }\end{array}$ & $\begin{array}{c}0.0933 \pm \\
0.0220 \\
b\end{array}$ \\
\hline Se & $\begin{array}{c}110.78 \pm \\
18.66 \\
\text { a }\end{array}$ & $\begin{array}{c}36.97 \pm 4.91 \\
\mathrm{a}\end{array}$ & $\begin{array}{c}5.14 \pm 0.73 \\
a\end{array}$ & $\begin{array}{c}1.257 \pm \\
0.184 \\
a\end{array}$ & $\begin{array}{c}0.0325 \pm \\
0.0117 \\
a\end{array}$ \\
\hline $\mathrm{Li}+\mathrm{Se}$ & $\begin{array}{c}101.50 \pm \\
22.79 \\
\text { a }\end{array}$ & $\begin{array}{c}34.08 \pm 4.51 \\
a\end{array}$ & $\begin{array}{c}4.67 \pm 0.59 \\
\mathrm{a}\end{array}$ & $\begin{array}{c}1.333 \pm \\
0.178 \\
a\end{array}$ & $\begin{array}{c}0.0370 \pm \\
0.0135 \\
a\end{array}$ \\
\hline
\end{tabular}

Values are mean \pm SD. Values in the column sharing the same superscript are statistically insignificant.

a lack of distinct differences between control and Se-group $(\mathrm{p}=0.37027)$, and particularly between control and $\mathrm{Li}+\mathrm{Se}-$ group ( $\mathrm{p}=0.99986)$. Additionally, kidney lithium was significantly decreased in Se-administered animals, both alone and in co-treatment with $\mathrm{Li}$ vs. Li-alone administered group ( $\mathrm{p}=0.00433, \mathrm{p}=0.00028$, respectively) (Tab. 2).

Table 2. Content of the studied elements in kidney of rats receiving lithium and/or selenium in $\mu \mathrm{g} / \mathrm{g}$ of wet tissue.

\begin{tabular}{|c|c|c|c|c|c|}
\hline Group & $\mathrm{Fe}$ & $\mathrm{Zn}$ & $\mathrm{Cu}$ & $\mathrm{Mn}$ & $\mathrm{Li}$ \\
\hline C & $\begin{array}{c}56.44 \pm \\
15.58 \\
a\end{array}$ & $\begin{array}{c}23.83 \pm 2.77 \\
a\end{array}$ & $\begin{array}{c}6.08 \pm 1.65 \\
a\end{array}$ & $\begin{array}{c}0.670 \pm \\
0.101 \\
\mathrm{a}\end{array}$ & $\begin{array}{c}0.1844 \pm \\
0.0802 \\
a\end{array}$ \\
\hline $\mathrm{Li}$ & $\begin{array}{c}60.94 \pm 8.53 \\
a\end{array}$ & $\begin{array}{c}23.55 \pm 1.20 \\
a\end{array}$ & $\begin{array}{c}5.33 \pm 0.96 \\
a\end{array}$ & $\begin{array}{c}0.625 \pm \\
0.084 \\
\text { a }\end{array}$ & $\begin{array}{c}0.4827 \pm \\
0.1227 \\
b\end{array}$ \\
\hline Se & $\begin{array}{c}68.08 \pm 8.60 \\
a\end{array}$ & $\begin{array}{c}24.55 \pm 2.19 \\
a\end{array}$ & $\begin{array}{c}5.59 \pm 0.71 \\
a\end{array}$ & $\begin{array}{c}0.705 \pm \\
0.088 \\
\text { a }\end{array}$ & $\begin{array}{c}0.2729 \pm \\
0.1074 \\
a\end{array}$ \\
\hline $\mathrm{Li}+\mathrm{Se}$ & $\underset{\mathrm{a}}{60.50 \pm 6.44}$ & $\begin{array}{c}23.49 \pm 1.83 \\
a\end{array}$ & $\begin{array}{c}7.60 \pm 3.48 \\
a\end{array}$ & $\begin{array}{c}0.690 \pm \\
0.092\end{array}$ & $\begin{array}{c}0.1884 \pm \\
0.0340\end{array}$ \\
\hline
\end{tabular}

Values are mean \pm SD. Values in the column sharing the same superscript are statistically insignificant

\section{DISCUSSION}

In the presented experiment, lithium administration caused its accumulation in the organs of experimental animals. These findings are consistent with other study reports. The accumulation of lithium in liver and kidney has also been reported in male rats receiving lithium carbonate in drinking water, and this effect was also characterized by a dose-dependency [14]. Other researchers also found its accumulation in the brain of fish undergoing environmental lithium exposure [17].

In the current study, neither lithium nor selenium treatment disturbed homeostasis of the other studied microlements in the organs of male rats. This issue has already been studied but the results are not unanimous. According to Tandon et al., dietary lithium (lithium carbonate, $1.1 \mathrm{~g} / \mathrm{kg}$,) did not alter iron and manganese and decreased zinc and copper in liver of female rats receiving normal protein diet. However, in animals receiving food with either a low or high protein level, no changes were observed in the studied bioelements, except for increased manganese in those fed with low protein [30]. In contrast, Dhawan et al. found that in liver of healthy female rats, provided with the same dose of dietary lithium, iron was significantly decreased while copper and zinc enhanced [31]. Apart from being inconsistencies, the presented results show that such factors as dietary composition or gender may contribute to relationships between lithium and different bioelements homeostasis in organs.

No distinct relationships were observed by Grotto et al. between lithium and bioelements in male rats receiving orally edible mushrooms Lentinula edodes (100, 400 and $800 \mathrm{mg}$ / $\mathrm{kg}$ /day for 30 days). In liver, lithium content did not show significant differences among the treated groups vs. control, manganese was decreased in animals given a medium dose, while copper and iron were decreased in those receiving the highest dose. In kidney, in turn, the middle and highest doses significantly decreased lithium content, but this effect was accompanied only with a well-marked decrease in manganese in the $800 \mathrm{mg} / \mathrm{kg} /$ day treated group [32].

Chmielnicka and Nasiadek reported that in female rats administered orally with 10 or $20 \mathrm{mg} \mathrm{Li} / \mathrm{kg}$ b.w. for 5 weeks, serum and urinary lithium were enhanced in a very distinct dose-dependent way during the whole experiment. Copper in urine was also found to be markedly increased together with the duration of the treatment, but in this case, the differences between the studied groups were not so considerable, indicating that although lithium administration intensified $\mathrm{Cu}$ excretion by kidney, the Li dose is not a crucial factor [33].

Lithium therapy is also used in cases of manic depression with the aim of accelerating response to antidepressant drugs [1]. In several human studies, copper in the blood of depressive patients was found to be enhanced and treatment with antidepressants decreased it [19]. In the present study, the liver $\mathrm{Cu}$ in $\mathrm{Li}+\mathrm{Se}$-treated rats was not altered compared to control, but in kidney a slight increase was observed which could also indicate its intensified excretion with urine, although this issue needs further investigation.

The results of the current study concerning the lack of distinct relationships between zinc and lithium in organs were also partially confirmed by Skalny et al., who performed their study on male rats receiving zinc asparaginate intragastrically ( 5 or $15 \mathrm{mg} / \mathrm{kg} /$ day for 7 or 14 days). After 7 days, liver $\mathrm{Zn}$ was increased only in the group receiving the higher dose, while in kidney, no changes were observed in zinc content, compared to control with no treatment. Liver lithium content, in turn, was not altered by any dose of zinc asparaginate vs. control, while in kidney, Li was decreased by the lower dose and enhanced by the higher one. After 14 days, in both organs, $5 \mathrm{mg}$ of $\mathrm{Zn}$ asparaginate did not affect zinc content, while the $15 \mathrm{mg}$ dose caused its significant increase vs. control. Compared to control, lithium was depressed in liver and enhanced in kidney. As a summary of the obtained results revealed, the enhancement of kidney lithium after the 14-day-treatment was accompanied with its decrease in other organs (liver, heart and muscle gastrocnemius), the authors suggested that this might be caused by the intensification of lithium urinary excretion in rats treated with zinc [34]. Such results support the usefulness of the animal model and allow the presumption that the lack of any changes of liver and kidney zinc observed in the current experiment, to be a fact of considerable importance. The additional support for such an assumption can be the findings reported by Chadha et al. 
whose research suggested the protective role of zinc against lithium hepatotoxicity [13].

A connection between lithium and different bioelements with kidney disturbances was also found in a recent study. The authors reported increased serum level of many elements, such as lithium, calcium, zinc, nickel, strontium and copper, accompanied by decreased iron in patients suffering from bladder cancer compared to healthy control, which led them to the conclusion that lithium, together with other elements like calcium, nickel and strontium, could be potential markers of bladder cancer [35].

The unchanged zinc content in the studied organs of rats receiving selenium seem to be a fact of great significance, considering the evidence of involvement of this element into the pathogenesis of depression, as well as its beneficial therapeutic effects in the cure of this disorder, including the enhancing the action of antidepressants. It is worth emphasizing that lithium is also used to potentiate the action of anti-depressive drugs [1].

Disturbances of iron homeostasis also proved to be connected with psychiatric disturbances [1]. The lack of even an insignificant difference between Fe in liver and kidney of animals treated simultaneously with $\mathrm{Li}$ and $\mathrm{Se}$, seems to be additional support for the assumption that selenium could be a beneficial adjuvant in cases of psychiatric disorders treated with lithium.

Selenium level in diet may alter the profile of bioelements in plasma and organs, and the trends of the observed changes are different, which once again supports the usefulness of the animal model. Erkekoglu et al. found that an abnormal selenium level in diet (deficit or supplemented) resulted in decreased zinc, but unchanged $\mathrm{Cu}, \mathrm{Mn}$ and $\mathrm{Fe}$ in plasma of male rats. In contrast, the influence of abnormal selenium in organs was different from that in liver where no effects were observed while in kidney, high Se enhanced $\mathrm{Zn}$ and decreased $\mathrm{Cu}$ and $\mathrm{Mn}$, whereas low Se diminished only Mn [36].

The lack of effect of any applied treatment on the studied elements also seems to be of great importance considering the fact that they all form the constituents of antioxidant enzymes, and the pro-oxidative effects of Li exposure has been revealed with zinc showing a protective effect [37].

\section{CONCLUSIONS}

The results of the presented experiment suggest that selenium could be regarded as an adjuvant into lithium therapy. However, considering the limitations of the present study, e.g. short duration of treatment, using only one dose and one (inorganic) form of selenium, continuation of the research seems to be necessary, aimed at clarifying the influence of selenium supplementation on basic microelements and lithium accumulation in organs during lithium exposure.

\section{Conflict of interest}

The authors declare that they have no conflict of interest.

\section{REFERENCES}

1. Młyniec K, Davies CL, de Agüero Sánchez IG, Pytka K, Budziszewska B, Nowak G. Essential elements in depression and anxiety. Part I. Pharmacol Rep. 2014; 66(4): 534-544.

2. Saad AB, Rjeibi I, Alimi H, Ncib S, Smida A, Zouari N, et al. Lithium induced, oxidative stress and related damages in testes and heart in male rats: The protective effects of Malva sylvestris extract. Biomed Pharmacother. 2017; 86: 127-135.

3. Gupta S, Khastgir U. Drug information update. Lithium and chronic kidney disease: debates and dilemmas. BJPsych Bull. 2017; 41(4): 216-220.

4. Amerio A, Ossola P, Scagnelli F, Odone A, Allinovi M, Cavalli A, et al. Safety and efficacy of lithium in children and adolescents: A systematic review in bipolar illness. Eur Psychiatry. 2018; 54: 85-97.

5. Peixoto-da-Silva J, Calgarotto AK, Rocha KR, Palmeira-DosSantos C, Smaili SS, Pereira GJS, et al. Lithium, a classic drug in psychiatry, improves nilotinib-mediated antileukemic effects. Biomed Pharmacother. 2018; 99: 237-244.

6. Hammond EN, Vangu MD. Effect of adjuvant lithium on thyroxine (T4) concentration after radioactive iodine therapy. Eur J Nucl Med Mol Imaging. 2016; 43(11): 1980-1987.

7. Shetty RK, Vivek G, Parida A, Chetty S. Lithium-induced sinus node dysfunction at therapeutic levels. BMJ Case Rep. 2013; 2013: pii: bcr2012008107.

8. Murru A, Popovic D, Pacchiarotti I, Hidalgo D, León-Caballero J, Vieta E. Management of adverse effects of mood stabilizers. Curr Psychiatry Rep. 2015; 17: 603.

9. Meehan AD, Humble MB, Yazarloo P, Järhult J, Wallin G. The prevalence of lithium-associated hyperparathyroidism in a large Swedish population attending psychiatric outpatient units. J Clin Psychopharmacol. 2015; 35(3): 279-285.

10. Ben Saad A, Dalel B, Rjeibi I, Smida A, Ncib S, Zouari N, et al. Phytochemical, antioxidant and protective effect of cactus cladodes extract against lithium-induced liver injury in rats. Pharm Biol. 2017; 55(1): 516-525.

11. Bocchetta A, Cabras F, Pinna M, Poddighe A, Sardu C, Ardau R, et al. An observational study of 110 elderly lithium-treated patients followed up for 6 years with particular reference to renal function Int J Bipolar Disord. 2017; 5(1): 19.

12. Kazandjieva J, Tsankov N. Drug-induced acne. Clin Dermatol. 2017; 35(2): 156-162.

13. Chadha VD, Bhalla P, Dhawan D. Uptake and retention of $65 \mathrm{Zn}$ in lithium-treated rat liver: role of zinc. Dig Liver Dis. 2010; 42(6): 446-450.

14. Toplan S, Ozdemir S, Tanriverdi G, Akyolcu MC, Ozcelik D, Darıerli N. The Effects of Lithium Administration on Oxidant/Antioxidant Status in Rats: Biochemical and Histomorphological Evaluations. Biol Trace Elem Res. 2016; 169(2): 279-284.

15. Tsermpini EE, Zhang Y, Niola P, Chillotti C, Ardau R, Bocchetta A, et al. Pharmacogenetics of lithium effects on glomerular function in bipolar disorder patients under chronic lithium treatment: a pilot study. Neurosci Lett. 2017; 638: 1-4.

16. Kerckhoffs APM, Hartong EGTM, Grootens KP. The perspectives of patients with lithium-induced end-stage renal disease. Int J Bipolar Disord. 2018; 6:13.

17. Tkatcheva V, Poirier D, Chong-Kit R, Furdui VI, Burr C, Leger R, et al. Lithium an emerging contaminant: bioavailability, effects on protein expression, and homeostasis disruption in short-term exposure of rainbow trout. Aquat Toxicol. 2015; 161: 85-93.

18. Oktem F, Ozguner F, Sulak O, Olgar S, Akturk O, Yilmaz HR, et al. Lithium-induced renal toxicity in rats: protection by a novel antioxidant caffeic acid phenethyl ester. Mol Cell Biochem. 2005; 277(1-2): 109-115.

19. Młyniec K, Gaweł M, Doboszewska U, Starowicz G, Pytka K, Davies CL, et al. Essential elements in depression and anxiety. Part II. Pharmacol Rep. 2015; 67(2): 187-194.

20. Weber SU, Lehmann LE, Schewe JC, Thiele JT, Schröder S, Book M, et al. Low serum alpha-tocopherol and selenium are associated with accelerated apoptosis in severe sepsis. Biofactors. 2008; 33(2):107-119.

21. Hu XF, Sharin T, Chan HM. Dietary and blood selenium are inversely associated with the prevalence of stroke among Inuit in Canada. J Trace Elem Med Biol. 2017; 44: 322-330.

22. Yao H, Zhao X, Fan R, Sattar H, Zhao J, Zhao W, et al. Selenium deficiency-induced alterations in ion profiles in chicken muscle. PLoS One. 2017; 12(9): e0184186.

23. Sivrikaya A, Bicer M, Akil M, Baltaci AK, Mogulkoc R. Effects of zinc supplementation on the element distribution in kidney tissue of diabetic rats subjected to acute swimming. Biol Trace Elem Res. 2012; 147(1-3): 195-199. 
24. Gunes S, Sahinturk V, Uslu S, Ayhanci A, Kacar S, Uyar R. Protective Effects of Selenium on Cyclophosphamide-Induced Oxidative Stress and Kidney Injury. Biol Trace Elem Res. 2018; 185(1): 116-123.

25. Musik I, Kiełczykowska M, Kocot J. Oxidant balance in brain of rats receiving different compounds of selenium. Biometals. 2013; 26(5): $763-771$.

26. Kiełczykowska M, Musik I, Hordyjewska A, Boguszewska A Lewandowska A, Pasternak K. Oral administration of lithium increases tissue magnesium contents but not plasma magnesium level in rats. Pharmacol Rep. 2007; 59(3): 291-295.

27. Gu QP, Xia YM, Ha PC, Butler JA, Whanger PD. Distribution of selenium between plasma fractions in guinea pigs and humans with various intakes of dietary selenium. J Trace Elem Med Biol. 1998; 12(1): 8-15.

28. Nciri R, Allagui MS, Croute F, Vincent C, Elfeki A. [Effects of low doses of Li carbonate injected into mice. Functional changes in kidney seem to be related to the oxidative status]. C R Biol. 2008; 331(1):23-31. [In French]

29. Kiełczykowska M, Kopciał E, Kocot J, Kurzepa J, Marzec Z, Musik I. Lithium disturbs homeostasis of essential microelements in erythrocytes of rats: Selenium as a protective agent? Pharmacol Rep. 2018; 70(6): 1168-1172.

30. Tandon A, Nagpaul JP, Bandhu H, Singh N, Dhawan DK. Effect of lithium on hepatic and serum elemental status under different dietary protein regimens. Biol Trace Elem Res. 1999; 68(1): 51-62.
31. Dhawan D, Singh A, Singh B, Bandhu HK, Chand B, Singh N. Effect of lithium augmentation on the trace elemental profile in diabetic rats. Biometals. 1999; 12(4): 375-381.

32. Grotto D, Gerenutti M, Souza VCO, Barbosa F Jr. Deficiency of macroand micronutrients induced by Lentinula edodes. Toxicol Rep. 2015; 2: 401-404.

33. Chmielnicka J, Nasiadek M. The trace elements in response to lithium intoxication in renal failure. Ecotoxicol Environ Saf. 2003; 55(2): 178183.

34. Skalny AA, Tinkov AA, Medvedeva YS, Alchinova IB, Karganov MY, Ajsuvakova OP, et al. Zinc asparaginate supplementation induces redistribution of toxic trace elements in rat tissues and organs. Interdiscip Toxicol. 2015; 8(3): 131-138.

35. Wach S, Weigelt K, Michalke B, Lieb V,Stoehr R, Keck B, et al. Diagnostic potential of major and trace elements in the serum of bladder cancer patients. J Trace Elem Med Biol. 2018; 46, 150-155.

36. Erkekoglu P, Arnaud J, Rachidi W, Kocer-Gumusel B, Favier A, Hincal F. The effects of di(2-ethylhexyl) phthalate and/or selenium on trace element levels in different organs of rats. J Trace Elem Med Biol. 2015; 29: 296-302.

37. Bhalla P, Chadha VD, Dhar R, Dhawan DK. Neuroprotective effects of zinc on antioxidant defense system in lithium treated rat brain. Indian J Exp Biol. 2007; 45(11): 954-958.

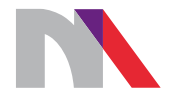

Ministry of Science and Higher Education

Republic of Poland

Generation of the DOI (Digital Object Identifier) - task financed under the agreement No. 618/P-DUN/2019 by the Minister of Science and Higher Education 